ISSN 1392-3196 / e-ISSN 2335-8947

Zemdirbyste-Agriculture, vol. 106, No. 1 (2019), p. 29-36

DOI 10.13080/z-a.2019.106.004

\title{
A comparative study of morphophysiological characteristics of flax in controlled and natural environmental conditions
}

\author{
Konstantin KOROLYOV ${ }^{1}$, Nina BOME ${ }^{1}$, Larissa WEISFELD ${ }^{2}$ \\ ${ }^{1}$ Institute of Biology, Tyumen State University \\ 6 Volodarskogo, 602003 Tyumen, Russia \\ E-mail: corolev.konstantin2016@yandex.ru \\ ${ }^{2}$ N. M. Emanuel Institute of Biochemical Physics of Russian Academy of Sciences \\ 4 Kosygina, 119334 Moscow, Russia
}

\begin{abstract}
Genetic diversity of plants increases the possibility of choice and provides higher adaptability of plants to adverse environmental conditions. Flax (Linum usitatissimum L.) is one of the crops requiring attention and introduction in agricultural production. In Siberia, Russia already in 1908 the first experiments with flax were started in Tobolsk province. In the $20^{\text {th }}$ century this branch was developed on the farms of Tyumen region. Heat resources, agrochemical properties of soils, water supply are adequate for the cultivation of this crop in the northern latitudes. The study was aimed to explore the effects of seed treatment with phosphemidum on chlorophyll content and morphometric parameters of flax seedlings and plants. Seventeen samples of fibre flax and three samples of linseed of different origin (Russia, Belarus, Ukraine, Canada, Czech Republic, France and Germany) from the collection of the Institute of Biology of Tyumen State University were studied. Air-dried seeds were treated with the solution of chemical agent phosphemidum in concentrations of $0.005,0.01$ and $0.1 \%$. Laboratory experiments revealed differences in morphometric parameters of plant seedlings. The response to seed treatment with mutagen was studied by the variability of chlorophyll content in the leaves. The samples were found to differ in the dynamics of chlorophyll accumulation by the stages of ontogenesis. All samples reacted to the increase of phosphemidum concentration by the decrease in chlorophyll content in leaves.
\end{abstract}

Key words: chlorophyll counter, mutagen, phosphemidum, SPAD-502, stressor.

\section{Introduction}

Abiotic and biotic stresses can affect morphophysiological and biochemical state of a plant by changing its metabolism, growth and development. The application of different agronomic practices, selection and genetic measures for increasing plant resistance to stressors (heat, drought, frost, cold, salinization, diseases and pests) are one of the key economic tasks. Searching for the stress-resistant cultivars is a solution to this problem, which does not require enormous technical investment at all stages of flax development. Consequently, the selection of plant forms with new, maybe unique characters and properties, and creation of cultivars on their basis is an important direction in agricultural science.

The effectiveness of creation and selection of initial material considerably increases in concrete soil and climatic conditions, because ecological factors characteristic of the given territory are a powerful selection background for the plant vitality. The agricultural territory of Tyumen region, Russia which is characterized by hard and contrasting conditions, both in space and time can be considered as a natural testing area for evaluation and choice of plants valuable for breeding. The fibre flax belongs to the most important agricultural crops in the world; its production area amounts to 3.4 million ha. In Europe, flax crops occupy 598 thousand hectares. The leading countries in flax cultivation are India - 930000 ha, Canada - 811500 ha, China - 570000 ha, USA - 135200 ha, Germany - 110 100 ha (FAO, http://www.fao.org/faostat).

The selection of cultivars and creation of new forms of fibre flax for specific environmental conditions, as well as extension of flax cultivation area require the application of effective methods for increasing genetic diversity, including experimental mutagenesis.

From physical mutagens, the gamma radiation of $\mathrm{Co}^{60}$ was effective on flax (Levchuk et al., 2009). Chemical mutagens are represented by $N$-nitroso- $N$ methylurea urea (NMU) (Kupyanskya, 1978; Sachkova, 2010), $N$-nitroso- $N$-ethylurea urea (NEU) and dimethyl sulfate (DMS) (Ivashko, 1988), ethyl methane sulfonate (EMS) (Rowland, 1991; Mohd et al., 2015) and sodium

Please use the following format when citing the article:

Korolyov K., Bome N., Weisfeld L. 2019. A comparative study of morphophysiological characteristics of flax in controlled and natural environmental conditions. Zemdirbyste-Agriculture, 106 (1): 29-36. DOI 10.13080/z-a.2019.106.004 
azide $\left(\mathrm{NaN}_{3}\right)$ (Bretagne-Sagnard, 1995; Ambreen, 2011), nitrosoguanidine (Korolev et al., 2017). A number of authors have indicated rather high sensitivity of flax cultivars to chemical mutagens (Green, Marshall, 1984; Green, 1986; Soto-Cerda et al., 2013; Chantreau et al., 2013; 2014).

Chemical and structural formula of phosphemidum: di-(ethyleneimine) pyrimidyl-2-amidophosphoric acid (Fig. 1).<smiles>O=P(Nc1ccccn1)(N1CC1)N1CC1</smiles>

Figure 1. Phosphemidum sin. phosphasin

Phosphemidum contains two ethyleneimine groups. Ethyleneimine is able to form chemical compounds with DNA, RNA and proteins of cells with rupture of gene and chromosome strands; ethylenimine caused a significant number of mutations in Drosophila (Rapoport, 1993). Phosphemidum contains pyrimidine base connected to amidophosphoric acid. It is expected that the pyrimidine base promotes the inclusion of mutagen in the DNA structure. This allows the mutagen to remain in the cells for a long time. The chemical agent phosphemidum represents a crystal powder soluble in hot water, alcohol, benzine and acetic acid. The effect of phosphemidum was studied on the model plants Crepis capillaris L. (Weisfeld, 2012), Triticum aestivum L. (Bome et al., 2017 a) and Hordeum vulgare L. (Bome et al., 2017 b).

The purpose of this work was to study the content of chlorophyll in leaves of fibre flax and linseed in controlled and natural environmental conditions in response to the chemical stressor.

\section{Materials and methods}

The experiments were conducted in 2016 and 2017. The collection of fibre flax and linseed (Linum usitatissimum L.) samples from Russia ('Pecherskiy kryazh', 'Velizhskiy kryazh', 'Rycheek', 'Fliz' and 'Biriuza'), Belarus ('Yarok', 'Iva', 'Grant', 'Mayak', 'Vesta', 'Rubin' and 'Mara'), Ukraine ('Glinum'), France ('Alizee'), Germany ('Bertelsdorfer'), Canada ('Ottava 770 B See'), and Czech Republic ('Hermes', 'Svalof' and 'Currong') were used as the experimental material. 'Rycheek', 'Fliz' and 'Biriuza' are linseed cultivars, other samples are fibre flax cultivars.

In spite of the difference in the geographic origin, the seed coat of most of the samples was of brown colour of different intensity. Only one sample 'Ottava 770 B See' had seeds of yellow colour. Considerable differences in 1000 seed weight were detected. The following samples belonged to the group with big seeds: 'Vesta' (5.57 g), 'Alizee' (5.48 g), 'Mara' (5.43 g), 'Ottava 770 B See' (5.37 g), 'Bertelsdorfer' (5.14 g), 'Yarok' (5.09 g), 'Grant' (5.04 g), and 'Iva' (5.03 g). For other samples, 1000 seed weight ranged from $4.13 \mathrm{~g}$ ('Pecherskiy kryazh') to 4.82 g ('Rubin').

Controlled conditions were created in the Laboratory of Biotechnological and Microbiological
Studies of the Department of Botany, Biotechnology and Landscape Architecture of the Institute of Biology of Tyumen State University, Russia.

The phosphemidum treatment of air-dry seeds of cultivars 'Yarok', 'Velizhskiy kryazh' and 'Ottava 770 B See' was performed in the draft hood at room temperature. The following concentrations of phosphemidum solution were studied: $0.005,0.01$ and $0.1 \%$. Seeds kept in the distilled water were used as control. After 8 hours' exposure, the seeds were washed in running water for 30 min and dried to $12 \%$ moisture. In every treatment of the experiments 600 seeds were treated.

The seeds were cultivated in Petri dishes in the thermostat TS-1/80 SPU (Russia) for 7 days. The germination energy and laboratory germination capacity were determined according to the State Standard of the Russian Federation (GOST) R 52325-2005 (Seeds of agricultural plants. Varietal and sowing characteristics. General specifications). The following morphometric parameters of seedlings were analysed: length of root and shoot, fresh and dry biomass. In order to study the peculiarities of early ontogenesis, samples were grown in vegetation vessels from inert material. The soil with optimal composition of nutrients $\left(\mathrm{N}-0.05, \mathrm{P}_{2} \mathrm{O}_{5}-0.1\right.$, $\mathrm{K}_{2} \mathrm{O}-0.06 \mathrm{~g} \mathrm{~kg}^{-1}$ soil) for flax cultivation was used. The soil volume in each vessel was 280 grams. Before sowing, the soil was moistened until $60 \%$ of full capacity. Twenty seeds were sown in each vessel. The cultivation of flax plants was performed on vegetation shelves with light of 5000 lux, 16-hour photoperiod. The arrangement of vessels with different varieties was randomized.

The height of plants, number and linear size (length, width) of leaves were measured every five days. The chlorophyll content was determined using an optical chlorophyll counter SPAD 502 (Minolta Camera Co Ltd., Japan).

Field experiments were performed at the experimental plot of Kuchak Lake Biological Station $\left(57.35^{\circ} \mathrm{N}, 66.06^{\circ} \mathrm{E}\right)$ of Tyumen State University, Tyumen region, Russia (Table 1).

Table 1. Description of the research site (Kuchak Lake Biological Station, Tumen State University)

\begin{tabular}{lc}
\hline \multicolumn{1}{c}{ Criteria } & Indicators \\
\hline Distance from Tyumen city, $\mathrm{km}$ & 50 \\
Altitude above sea level, $\mathrm{m}$ & 61 \\
Climate type & distinctly continental \\
Mean annual air temperature, ${ }^{\circ} \mathrm{C}$ & 0.3 \\
Mean annual precipitation, $\mathrm{mm}$ & 457 \\
Soil type & turf-podzol, loamy sandy \\
Soil pH & 6.6 \\
Humus, $\%$ & 3.67 \\
\hline
\end{tabular}

Sowing was carried out within the first ten days of May, when the soil temperature reached $10^{\circ} \mathrm{C}$ at a depth of $8 \mathrm{~cm}$. Harvesting was carried out during the period 20-25 August at the stage of full ripeness.

Experiments, surveys and observations were carried out according to the methodological recommendations (Methodical guidelines..., 1988) of the N. I. Vavilov Institute of Plant Genetic Resources (VIR).

The weather conditions during the field trial in 2017 were characterized by lower average daily temperature in May, June and July (by 1.1, 0.2, and $1.1^{\circ} \mathrm{C}$ below the norm, respectively). In August, the air 
temperature exceeded the long-term average by $1.2^{\circ} \mathrm{C}$. Uneven distribution of precipitation during the vegetation period was observed. In May and June, the rainfall exceeded the long-term averages by $20.2 \mathrm{~mm}$ (May) to $52.0 \mathrm{~mm}$ (June). The lack of rainfall was recorded in July $(24.6 \mathrm{~mm})$ and August $(15.0 \mathrm{~mm})$.

Statistical processing of experimental data was performed using Microsoft Office Excel 2010 and SPSS, version $P A S W$ Statistics, $R$ version (Field et al., 2012).

\section{Results and discussion}

One of the main indicators that determine the biological potential of seeds is germination energy and laboratory germination capacity. In our experiment, germination of seeds in Petri dishes showed that the seeds of all the samples were characterized by high germination energy. This indicator varied in different fibre flax cultivars from 93.7\% ('Yarok') to $99.8 \%$ ('Velizhskiy kryazh'), in linseed, from $96.8 \%$ ('Fliz') to $98.5 \%$ ('Biriuza'). The highest indicator (99.8\%) of laboratory germination was recorded in the cultivar 'Grant' (Fig. 2). In vegetation vessels, flax shoots appeared on the $5^{\text {th }}-7^{\text {th }}$ day, the proportion of germinated seeds varied from $66.9 \%$ ('Pechersky kryazh') to $85.3 \%$ ('Svalof').
For the selection of valuable genotypes, important additions to traditional seed testing methods based on new knowledge of molecular biology, biotechnology, biophysics, and seed physiology are proposed already at the initial stages of ontogenesis (Filho, 2015).

Various markers are used in the laboratory and field testing of genotypes for resistance to environmental factors. For example, it has been shown that plant height, superoxide dismutase and catalase activity, glutathione content, the number of days before flowering, 1000 seed weight and crop capacity are suitable for screening large populations and selecting valuable millet forms in the Central Himalayan region (Trivedi et al., 2017).

A better understanding of the cellular, molecular and biochemical mechanisms that determine physiological potential of seeds is associated with the identification of markers, which include the chlorophyll content (Cicero et al., 2009; Dell'Aquila, 2009). Along with laboratory methods, an optical chlorophyll counter SPAD 502 (Minolta Camera Co. Ltd.) is used to determine the chlorophyll content in leaves of Triticum durum plants (Kendal, 2015). The relationship between the chlorophyll concentrations in leaves measured by the SPAD 502 meter and the productivity and quality of

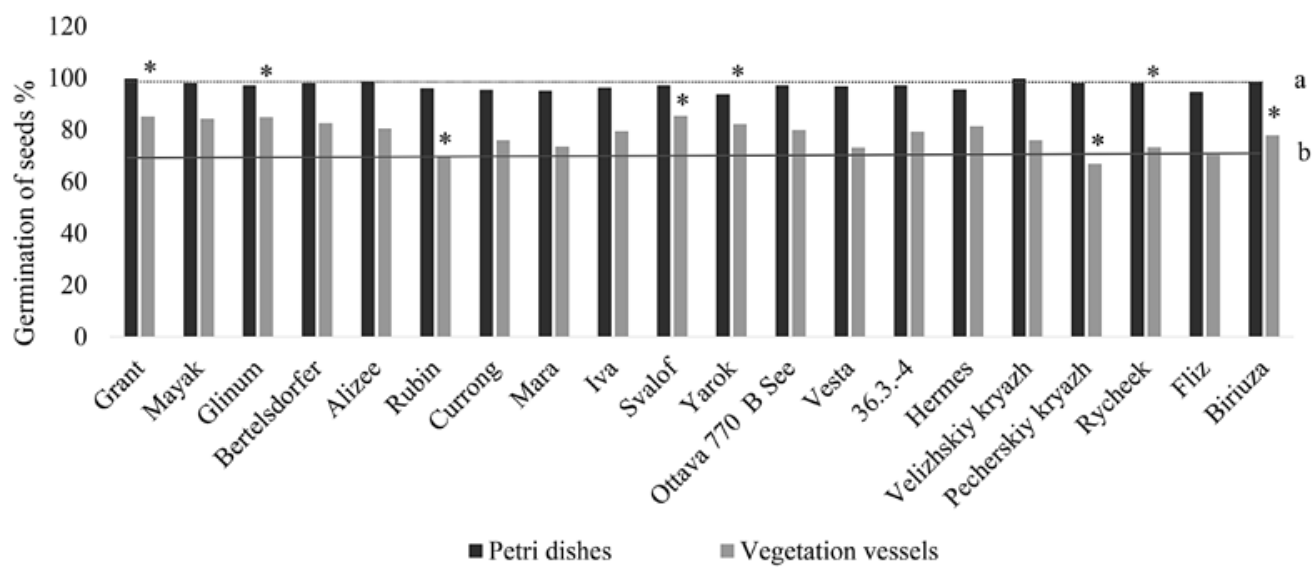

Note. ${ }^{*}$ - the differences are statistically significant when comparing the studied samples with the average population value for seed germination in Petri dishes (a) and vegetation vessels (b), at $P>95 \%$.

Figure 2. Germination of seed samples of fibre flax and linseed cultivated in Petri dishes and vegetation vessels

some plant species, including agricultural crops (wheat and potato), was reported by Uddling et al. (2007).

Analysis of the SPAD 502 readings revealed a general pattern for the fibre flax and linseed, which was manifested in the positive dynamics of chlorophyll accumulation in the leaf cells in early plant ontogenesis (Table 2). It is noteworthy that for samples of fibre flax the relative rate of chlorophyll accumulation was maximal between the second and the first measurement (an increase of 3.6 times), while in linseed seeds, this process passed uniformly (an increase of 1.8 times in both measurements).

Along with traditionally used selection-valuable characters, the indicator of chlorophyll content in leaves was included in the complex evaluation of flax samples in the field, which can help to some extent understand how the data, obtained in the laboratory conditions, can be interpreted for the conditions of field experiment.

Complete shoots of flax appeared on the $6^{\text {th }}-7^{\text {th }}$ day after sowing. The field germination ranged from
Table 2. Chlorophyll content in flax collection samples $(\mathrm{n}=20)$ (laboratory experiment, 2016)

\begin{tabular}{cccc}
\hline \multirow{2}{*}{ Index } & \multicolumn{3}{c}{ Stage of plant development } \\
\cline { 2 - 4 } & $1^{* *}$ Fibre flax \\
\hline \multicolumn{4}{c}{2} \\
\hline $\mathrm{X} \pm \mathrm{S}_{\mathrm{x}}$ & $1.29 \pm 0.52^{*}$ & $4.66 \pm 0.45$ & $9.14 \pm 0.47$ \\
Min & $0.11 \pm 0.77$ & $1.99 \pm 0.18$ & $3.43 \pm 0.21$ \\
Max & $2.79 \pm 0.18$ & $10.32 \pm 0.98$ & $16.50 \pm 0.37$ \\
$\mathrm{CV} \%$ & 9.92 & 7.31 & 10.68 \\
\hline \multicolumn{4}{c}{ Linseed } \\
\hline $\mathrm{X} \pm \mathrm{S}_{\mathrm{x}}$ & $4.30 \pm 0.42$ & $7.86 \pm 0.61$ & $14.37 \pm 0.51$ \\
Min & $3.25 \pm 0.26$ & $6.43 \pm 0.64$ & $11.3 \pm 0.56$ \\
Max & $5.21 \pm 0.59$ & $9.22 \pm 0.77$ & $16.23 \pm 0.78$ \\
$\mathrm{CV} \%$ & 7.03 & 6.42 & 5.33 \\
\hline
\end{tabular}

Note. CV - coefficient of variation, * - differences between mean values were significant at $95 \%$ confidence level; ** 1 - shoots (17 12 2016), 2 - formation of the $1^{\text {st }}$ pair of true leaves (22 12 2016), 3 - formation of $5^{\text {th }}-6^{\text {th }}$ pairs of true leaves (27 12 2016). 
$54.3 \%$ to $81.2 \%$ and was lower than the laboratory germination. In the initial period, the fibre flax and linseed grow slowly, intensively developing the root system; further average daily increments of the aboveground biomass increase, reaching a maximum during the flowering period, and then decrease (D'yakov, 2006). Positive relationships between the accumulation of biomass and the content of chlorophyll were revealed. Determination of the chlorophyll content was carried out in the flax samples for periods selected according to the BBCH scale: shoots (06-09), start of leaf spiral (11-19), rapid growth (30-39), budding (50-59), flowering (58$67)$, green ripeness (69-79) and early yellow ripeness (83-90) (Table 3).

Table 3. Chlorophyll content in flax collection samples $(\mathrm{n}=20)$ (field experiment, 2017)

\begin{tabular}{cccccccc}
\hline & \multicolumn{7}{c}{ Stage of ontogenesis / code on a BBCH scale } \\
\cline { 2 - 8 } Index & $\begin{array}{c}\text { shoots } \\
(09-10)\end{array}$ & $\begin{array}{c}\text { start of } \\
\text { leaf spiral } \\
(11-19)\end{array}$ & $\begin{array}{c}\text { rapid growth } \\
(30-39)\end{array}$ & $\begin{array}{c}\text { budding } \\
(50-59)\end{array}$ & $\begin{array}{c}\text { flowering } \\
(58-67)\end{array}$ & $\begin{array}{c}\text { green ripeness } \\
(69-79)\end{array}$ & $\begin{array}{c}\text { early yellow } \\
\text { ripeness } \\
(83-90)\end{array}$ \\
\hline \multicolumn{7}{c}{ Fibre flax } \\
\hline $\mathrm{X} \pm \mathrm{S}_{\mathrm{x}}$ & $2.44 \pm 0.78^{*}$ & $17.86 \pm 0.90^{*}$ & $25.15 \pm 0.54^{*}$ & $38.07 \pm 0.80^{*}$ & $51.28 \pm 0.19$ & $20.62 \pm 1.23^{*}$ & $7.05 \pm 0.85^{*}$ \\
Min & $1.59 \pm 0.54$ & $10.03 \pm 0.30$ & $15.47 \pm 0.47$ & $26.71 \pm 0.43$ & $33.45 \pm 0.87$ & $10.34 \pm 1.09$ & $4.23 \pm 0.59$ \\
Max & $3.56 \pm 0.89$ & $28.34 \pm 0.56$ & $40.87 \pm 0.89$ & $58.78 \pm 0.44$ & $70.05 \pm 0.21$ & $39.07 \pm 0.33$ & $12.89 \pm 0.33$ \\
$\mathrm{CV} \%$ & 8.22 & 12.31 & 12.35 & 10.45 & 15.87 & 10.54 & 9.38 \\
\hline \multicolumn{7}{c}{ Linseed } \\
\hline $\mathrm{X} \pm \mathrm{S}_{\mathrm{x}}$ & $4.66 \pm 0.23^{*}$ & $9.14 \pm 0.65^{*}$ & $18.55 \pm 0.12^{*}$ & $31.55 \pm 0.45^{*}$ & $51.76 \pm 1.01^{*}$ & $24.26 \pm 0.87^{*}$ & $11.22 \pm 1.11^{*}$ \\
$\mathrm{Min}$ & $2.34 \pm 0.16$ & $6.93 \pm 0.39$ & $16.23 \pm 0.21$ & $23.38 \pm 0.98$ & $47.29 \pm 0.54$ & $19.45 \pm 0.90$ & $9.23 \pm 1.06$ \\
$\mathrm{Max}$ & $7.21 \pm 0.434$ & $12.36 \pm 0.76$ & $21.21 \pm 0.89$ & $38.07 \pm 0.21$ & $56.77 \pm 0.76$ & $29.89 \pm 0.76$ & $13.23 \pm 0.98$ \\
$\mathrm{CV} \%$ & 8.33 & 10.20 & 12.24 & 9.20 & 6.86 & 12.54 & 10.13 \\
\hline
\end{tabular}

Note. $\mathrm{CV}$ - coefficient of variation, * - differences between the mean values for the stages of ontogenesis when compared with each previous one are significant, $P=95 \%$.

The maximum chlorophyll content among the studied flax samples was observed during the plant flowering period. However, fibre flax and linseed samples differed according to the dynamics of chlorophyll accumulation. In fibre flax plants, the most intensive chlorophyll increase (7.3 times) was observed from the full shoots to start of leaf spiral stage. In linseed plants, the increase in chlorophyll content between measurements was uniform during the whole period form full shoots until flowering (1.6-2.0 times). The comparison of two flax species showed that linseed exceeded fibre flax in chlorophyll content during earlier stages of development, while at the stage start of leaf spiral, quick growth and budding it was vice versa. At the flowering stage no significant difference was observed. Entry into the stages of green ripeness and early ripeness in both flax species was accompanied by chlorophyll decrease, which is related mainly to yellowing and senescence of leaves.

The detected differences in the dynamics of accumulation and content of chlorophyll in leaves between the samples of the two flax species in the laboratory and field conditions suggest that these indicators can be applied when testing for resistance to stressors, both naturally appearing in the environment as well as created experimentally. We applied the chemical mutagen phosphemidum in three concentrations $(0.005$, 0.01 and $0.01 \%$ ) as a stressor. Until now, this mutagen has practically not been studied for flax. Consequently, our primary task was to detect lethal and optimal concentrations for obtaining first generation seeds $\left(M_{1}\right)$.

In the fibre flax cultivars 'Yarok', 'Velizhskiy kryazh' and 'Ottava 770 B See' in the treatments with phosphemidum a decrease in the laboratory germination capacity was observed. It was also noticed that germination capacity of seeds decreased with increasing mutagen concentration.

The differences in flax samples between minimum (0.10) and maximum (14.21) values relative to the control amounted to $12.6,42.4$ and $49.7 \%$ under low (0.005\%), medium (0.01\%) and high $(0.1 \%)$ concentrations, respectively. The laboratory germination in the control compared with the experimental treatments was significantly higher by $3.5 \%$ with a minimum value and by $4.5 \%$ with the maximum value of the mutagen. Any stimulating effect of the mutagen according to this character was not detected in the samples under study.

The ratio of shoot to root length can be one of the informative indicators of plant seedling reaction to the stressor. In 'Yarok' and 'Velizhskiy kryazh' cultivars in the control more intensive development of root system was observed (shoot:root ratio - 0.78:0.81). In stress conditions, roots still dominated, but their advantage was less expressed, as the shoot:root ratio decreased to 0.68 0.52 in 'Velizhskiy kryazh' and to $0.65-0.47$ in 'Yarok'. These data indicate that the difference in relative longwise growth of shoots and roots in stress conditions is less expressed than in the control. The seedlings of 'Ottava 770 B See' differed from those of the above-mentioned cultivars by more expressed domination of root over shoot (shoot:root ratio was 0.49 ). In the experiment this indicator decreased $(0.37-0.23)$. It is noteworthy that in spite of the detected considerable differences in shoot and root length among the flax samples and treatments of the experiment, no significant difference between the control and experimental treatments in fresh and dry biomass of seedlings was found.

In order to better understand the response of the cultivars to the mutagenic factor since the moment of seed germination, the readings of chlorophyll counter SPAD 502 were registered. The chlorophyll content varied among the experimental treatments, periods of measurement and genotypes. In the control, the lowest chlorophyll content under the first reading was observed in early-maturing 'Yarok' (1.46), the highest content of the pigment was observed in late-maturing 'Ottava 770 B See' (4.05), which we relate to the difference in the growth rate already at the early stages of ontogenesis. By the end of the experiment the counter readings were 
5.03 for 'Yarok' and 12.29 for 'Ottava 770 B See'. The highest sensitivity to phosphemidum was detected in 'Ottava 770 B See', which showed significant decrease of chlorophyll relative to the control during the whole period of observations (Fig. 3). The stimulating effect on chlorophyll was found for 'Yarok' at the first reading and for 'Velizhskiy kryazh' at the first and second readings.

For more detailed information on the variability of SPAD 502 readings, see Figure 4.
A

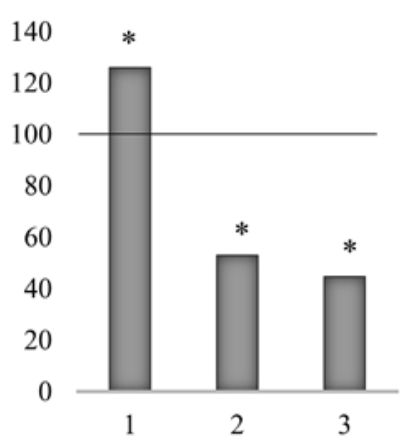

B

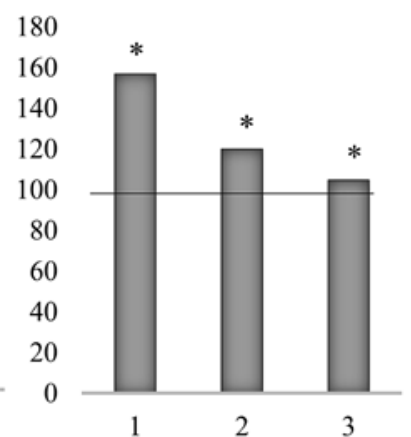

$\mathrm{C}$

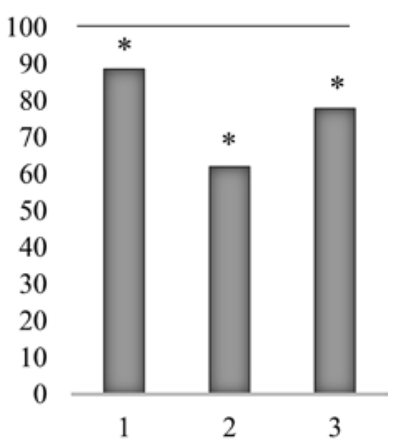

Note. Cultivars: A - 'Yarok', B - 'Velizhskiy kryazh', C - 'Ottava 770 B See'; horizontal line - control (100\%); 1, 2, 3 - dates of measurements (see Table 2); * - statistically significant values; on the ordinate is the numerical value of the character.

Figure 3. The effect of phosphemidum on the chlorophyll content in the leaves of fibre flax seedlings (\% to control)

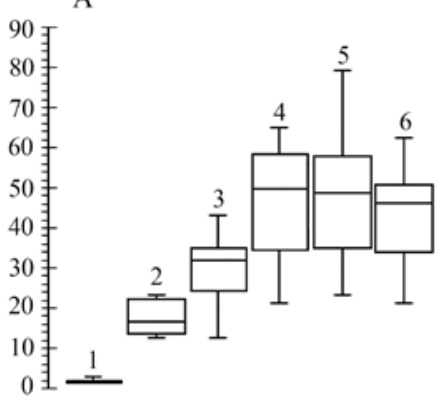

C

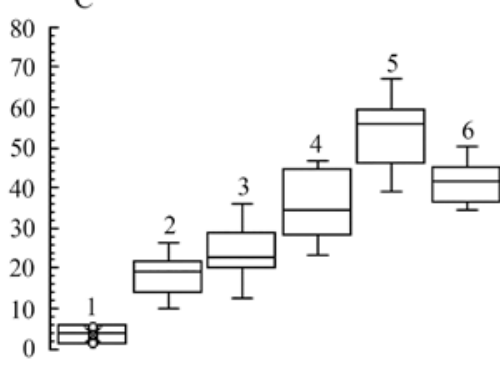

B

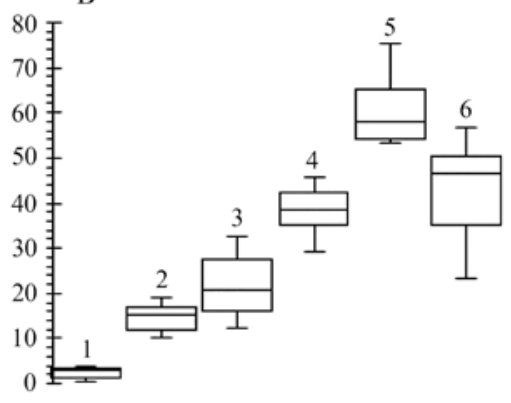

D

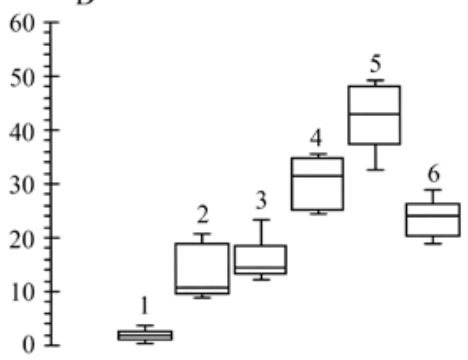

Note. Horizontal line shows mediana; $\square-$ the object formed between the lower and upper quartiles, whiskers represent minimum and maximum values; stages of plant development: 1 - seedlings, 2 - start of leaf spiral, 3 - quick growth, 4 - budding, 5 flowering, 6 - green ripening; phosphemidum concentration: A - control, B $-0.005 \%, \mathrm{C}-0.01 \%, \mathrm{D}-0.1 \%$; y-axis represents numeric value of character.

Figure 4. Phosphemidum influence on chlorophyll content at various stages of ontogenesis (field experiment, 2017)

In the field study, the same samples ('Yarok', 'Velizhskiy kryazh', 'Ottava 770 B See') according to the dynamics of chlorophyll accumulation behaved similarly as collection samples in the laboratory experiment, both in the control and in the phosphemidum treatments (Table 2).

The lowest content of the pigment in the control treatments was observed at the stage of full germination of seeds (0.56) and the highest content at the stage of flowering (79.12). The fibre flax sensitivity to the chemical mutagen displayed at different periods of development in the decrease of chlorophyll content, especially under high mutagen concentration $(0.1 \%)$.
The readings of the chlorophyll counter SPAD 502 in the treatment with a phosphemidum concentration of $0.1 \%$ ranged from 1.94 (full germination of seeds) to 42.34 (flowering) and then to 23.73 (green ripening). In the control treatment, a significant decrease in chlorophyll content was observed at the stage of full germination of seeds. In the experiments with phosphemidum treatment, a significant decrease in chlorophyll content was observed in all stages of ontogenesis compared with the control.

As it is known from the literature (Jhala et al., 2008; Vakula et al., 2009), the formation of characters of flax plants is affected by various factors, of which the environment and the interaction between genotype and environment are the leading ones. 
A three-factor analysis of variance (ANOVA) showed that the effects of genetic variability (genotype), growth conditions (environment), stressor (mutagen), as well as genotype $\times$ environment, genotype $\times$ mutagen, mutagen $\times$ environment interactions on the variation of chlorophyll content in leaves were significant (Table 4).

Correlative variability, as a prediction method for selection, is widely used in flax breeding (Rennebaum et al., 2002; Diederichsen, Raney, 2006; Diederichsen, 2007; Brach et al., 2010). Calculation of the correlation coefficients allowed us to identify the ratio of chlorophyll content to plant height $\left(R^{2}=0.65\right)$, the number of leaves $\left(R^{2}=0.36\right)$ and area of leaves $\left(R^{2}=0.19\right)$ under controlled conditions (Fig. 5).

In the conditions of field experiment the chlorophyll content was found to be most closely related to plant height $\left(R^{2}=0.8954\right)$ and number of leaves $\left(R^{2}=\right.$ 0.2503 ) (Fig. 6).
Table 4. Results of three-factor analysis of variance of the chlorophyll content

\begin{tabular}{lcccc}
\hline \multicolumn{1}{c}{ Source of variation } & $\mathrm{df}$ & $\mathrm{mS}$ & $F_{\text {fact. }}$ & $F_{0.05}$ \\
\hline Factor A (genotype) & 10 & $67.18^{*}$ & 5.45 & 3.55 \\
Factor B (environment) & 1 & $113.43^{*}$ & 11.56 & 4.41 \\
Factor C (mutagen) & 1 & $188.21^{*}$ & 35.33 & 18.51 \\
Interaction A × B & 1 & $97.33^{*}$ & 5.12 & 4.41 \\
Interaction A × C & 2 & $256.01 *$ & 31.01 & 19.43 \\
Interaction B $\times$ C & 2 & $311.22^{*}$ & 54.78 & 19.43 \\
Stochastic factor & 1 & 12.46 & 3.59 & 4.41 \\
\hline
\end{tabular}

Note. The main factors influencing the formation of chlorophyll in plants of long-stalked flax when treating seeds with phosphemidum in three different concentrations were medium $\times$ mutagen, genotype $\times$ mutagen and mutagen; $\mathrm{df}-$ degree of freedom, $\mathrm{mS}$ - mean square, $F_{\text {fact }}$ - real value of Fisher criterion, $F_{0.05}$ - the critical value of the Fisher test at a significance level 0.05 ; * - effect is significant under $P>95 \%$.
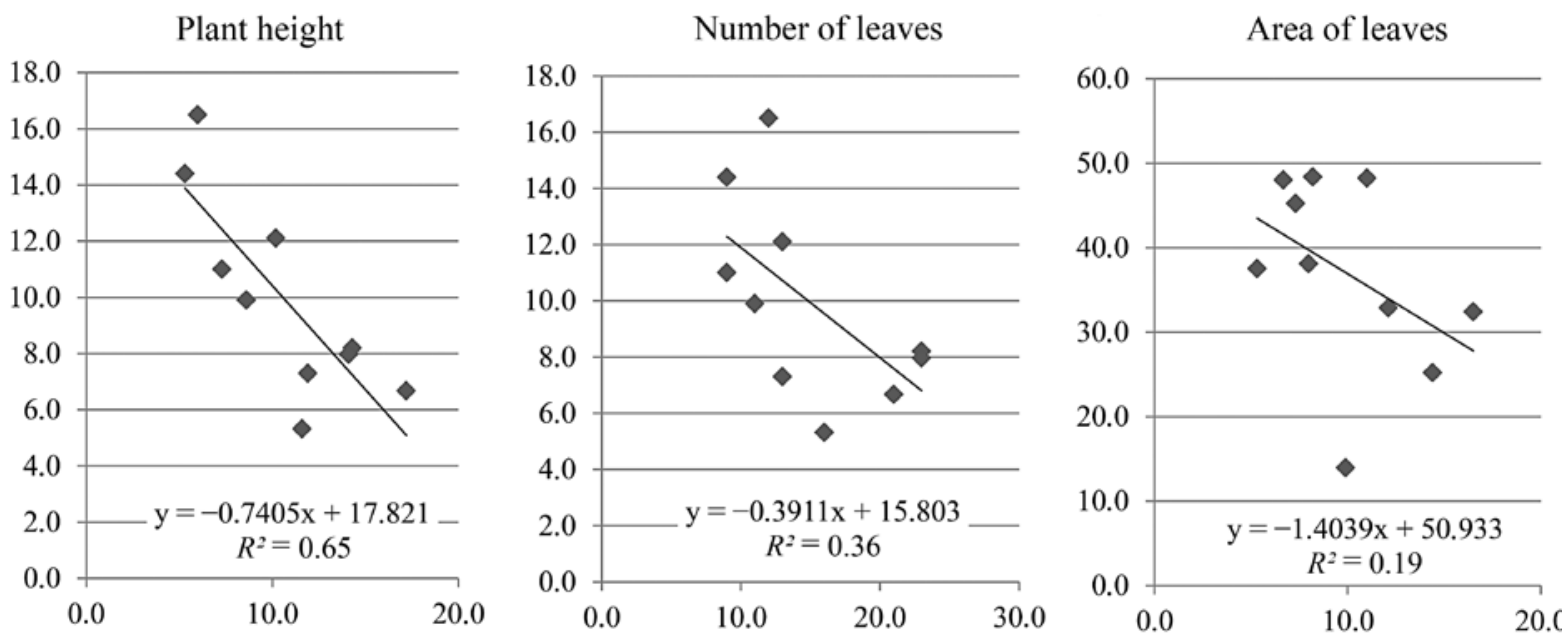

Note. On $\mathrm{x}$-axis are mean values of the characters, on $\mathrm{y}$-axis - chlorophyll content; $\mathrm{y}=-0.7405 \mathrm{x}+17.821, \mathrm{y}=-0.3911 \mathrm{x}+15.803$ and $\mathrm{y}=-1.4039 \mathrm{x}+50.933-$ the regression equations; $R^{2}-$ the coefficient of determination.

Figure 5. The correlation between chlorophyll content and plant height, number of leaves and area of leaves (laboratory experiment, 2017)
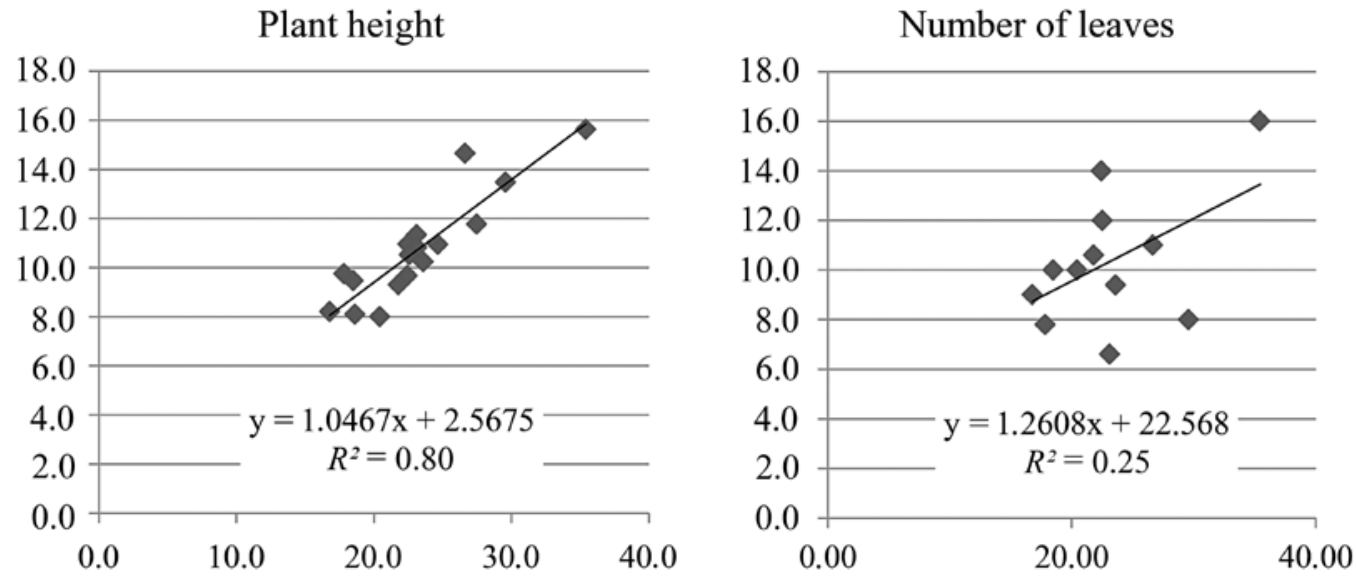

Note. On $\mathrm{x}$-axis are mean values of the characters; on $\mathrm{y}$-axis - chlorophyll content; $\mathrm{y}=1.0467 \mathrm{x}+2.5675$ and $\mathrm{y}=1.2608 \mathrm{x}+22.568$ - the regression equations; $R^{2}$ - the coefficient of determination.

Figure 6. The correlation of chlorophyll content with plant height and number of leaves (field experiment, 2017) 


\section{Conclusions}

1. Differences in the dynamics of accumulation and degradation of chlorophyll $a$ and $b$ in the leaves of fibre flax and linseed can be used in genotype screening.

2.A possibility of rapid monitoring of chlorophyll content in leaves and morphometric characteristics of plants in the early stages of ontogenesis is shown, which will make it possible to identify the biological potential of genotypes and increase the efficiency of selecting valuable flax forms.

3 . The revealed patterns of the variability of the studied features will be useful when flax is introduced into the conditions of the northern latitudes of Russia.

Received 16032018

Accepted 17092018

\section{References}

1. Ambreen A. 2011. Cytological effect of ethyl methane sulphonate and sodium azide in (Linum usitatissimum L.). International Journal of Plant, Animal and Environmental Sciences, 2 (1): 70-75.

2. Bome N., Weisfeld L., Babaev E., Bome A., Kolokolova N. 2017 (a). Influence of phosphemid, of chemical mutagen, on agrobiological characters of soft spring wheat Triticum aestivum L. Agricultural Biology, 52 (3): 570-579 (in Russian).

https://doi.org/10.15389/agrobiology.2017.3.570eng

3. Bome N., Weisfeld L., Korolev K., Tytanikov N. 2017 (b). The reaction of various plant species $\mathrm{M}_{1}$ on the influence of chemical mutagen phosphemid. The Successes of Modern Science, 1 (9): 121-124 (in Russian).

4. Brach N., Sharov I., Pavlov A., Porokhovinova E. 2010. Variability of flax characters, associated with fibre formation, and environmental influence on their expression. Ecological Genetics, 8 (1): 23-35 (in Russian).

https://doi.org/10.17816/ecogen8125-35

5. Bretagne-Sagnard B. 1995. Induced albino mutations as a tool for genetic analysis and cell biology in flax (Linum usitatissimum L.). Journal of Experimental Botany, 47 (295): 189-194.

6. Chantreau M., Grec S., Gutierrez L. et al. 2013. PT-Flax (phenotyping and TILLinG of flax): development of a flax (Linum usitatissimum L.) mutant population and TILLinG platform for forward and reverse genetics. BMC Plant Biology, 13: 159.

https://doi.org/10.1186/1471-2229-13-159

7. Chantreau M., Portelette A., Dauwe R. et al. 2014. Ectopic lignification in the flax lignified bast fiber1 mutant stem is associated with tissue-specific modifications in gene expression and cell wall composition. The Plant Cell, 26 (11): 4462-4482. https://doi.org/10.1105/tpc.114.130443

8. Cicero S., van der Schoor R., Halink H. 2009. Use of chlorophyll fluorescence sorting to improve soybean seed quality. Revista Brasileira de Sementes, 31 (4): 145-151. https://doi.org/10.1590/S0101-31222009000400017

9. D'yakov A. 2006. Physiology and ecology of flax. Krasnodar, Russia, 214 p. (in Russian).

10. Dell'Aquila A. 2009. Development of novel techniques in conditioning, testing and sorting seed physiological quality. Seed Science and Technology, 37 (3): 608-624. https://doi.org/10.15258/sst.2009.37.3.10
11. Diederichsen A. 2007. Ex situ collections of cultivated flax (Linum usitatissimum L.) and other species of the genus Linum L. Genetic Resources Crop Evolution, 54: 661-679. https://doi.org/10.1007/s10722-006-9119-Z

12. Diederichsen A., Raney J. 2006. Seed colour, seed weight and seed oil content in Linum usitatissimum L. accessions held by Plant Gene Resources of Canada. Plant Breeding, 125 (4): 372-377. https://doi.org/10.1111/j.1439-0523.2006.01231.x

13. Field A., Mieles J., Field Z. 2012. Discovering statistics using $R, 992 \mathrm{p}$.

14. Filho M. J. 2015. Seed vigor testing: an overview of the past, present and future perspective. Scientia Agricola, 72 (4): 363-374. https://doi.org/10.1590/0103-9016-2015-0007

15. Green A. G. 1986. A mutant genotype of flax (Linum usitatissimum L.) containing very low levels of linolenic acid in its seed oil. Canadian Journal of Plant Science, 66 (3): 499-503. https://doi.org/10.4141/cjps86-068

16. Green A. G., Marshall D. R. 1984. Isolation of induced mutants in linseed (Linum usitatissimum L.) having reduced linoleic acid content. Euphytica, 33 (2): 321-328.

https://doi.org/10.1007/BF00021128

17. Ivashko L. 1988. The use of mutagenesis method in the selection of flax. Chemical mutagenesis in the selection process, p. 158-160 (in Russian).

18. Jhala A., Hall L., Hall J. 2008. Potential hybridization of flax (Linum usitatissimum L.) with weedy and wild relatives: an avenue for movement of engineered genes? Crop Science, 48: 825-840.

https://doi.org/10.2135/cropsci2007.09.0497

19. Kendal E. 2015. Relationship between chlorophyll and other features in durum wheat (Triticum turgidum L. var. durum) using SPAD and Biplot analyses. Journal of Agricultural Science and Technology, 17 (6): 1873-1886.

20. Korolev K., Bome N., Abetova A. 2017. Mutation effect of nitrozoguanidine when exposed to flax varieties (Linum usitatissimum L.) of various ecological and geographical origins. Tobolsk Scientific: materials of the $16^{\text {th }}$ all-Russian scientific and practical conference, p. 84-87 (in Russian).

21. Kupyanskya N. 1978. The effect of chemical mutagens on flax. Breeding, Seed Growing and Agrotechnics of Flax Cultivation, 15: 3-5 (in Russian).

22. Levchuk G., Yarantseva V., Polyakova I. 2009. Influence of illumination level on pigmental composition in different types of chlorophyll mutants of oil flax. Zaporizhzhya National University, Ukraine, 6 p. (in Ukrainian).

23. Methodical guidelines for studying the collection of flax (Linum usitatissimum L.). 1988. Leningrad, Russia, 28 p. (in Russian).

24. Mohd G., Tariq A., Mohammad O. 2015. Mutants as a genetic resource for future crop improvement advance. Plant Breeding Strategies, 1: 95-114.

25. Rapoport J. A. 1993. The interaction between the ethyleneimine and the gene protein and hereditary variations. The discovery of chemical mutagenesis. Moscow, Russia, p. 111-125 (in Russian).

26. Rennebaum H., Grimm E., Warnstorff K., Diepenbrock W. 2002. Fibre quality of linseed (Linum usitatissimum L.) and the assessment of genotypes for use of fibres as a byproduct. Industrial Crops and Products, 16: 201-215. https://doi.org/10.1016/S0926-6690(02)00048-1

27. Rowland G. G. 1991. An EMS-induced low-linolenicacid mutant in McGregor flax (Linum usitatissimum L.). Canadian Journal of Plant Science, 71 (2): 393-396. https://doi.org/10.4141/cjps91-054 
28. Sachkova N. 2010. Varietal resources to increase the production of flax fiber. Scientific achievements-flax growing. Tver University, Russia, p. 55-57 (in Russian).

29. Soto-Cerda B. J., Diederichsen A., Ragupathy R., Cloutier S. 2013. Genetic characterization of a core collection of flax (Linum usitatissimum L.) suitable for association mapping studies and evidence of divergent selection between fiber and linseed types. BMC Plant Biology, 13: 78. https://doi.org/10.1186/1471-2229-13-78

30. Trivedi A., Arya L., Verma S., Tyagi R., Hemantaranjan A. 2017. Evaluation of barnyard millet diversity in central Himalayan region for environmental stress tolerance. Journal of Agricultural Science, 155: 1497-1507. https://doi.org/10.1017/S0021859617000545
31. Uddling J., Gelang-Alfredsson J., Piikki K., Pleijel H. 2007. Evaluating the relationship between leaf chlorophyll concentration and SPAD-502 chlorophyll meter readings. Photosynthesis Research, 91 (1): 37-46. https://doi.org/10.1007/s11120-006-9077-5

32. Vakula S., Leontiev V., Koren L., Titok V. 2009. Ecological variability of oil and protein content in flaxseed. Vagos, 82 (35): 77-81.

33. Weisfeld L. 2012. Damages of chromosomes and divisions of mitotic activity in plantlets of Crepis capillaris by alkylating antineoplastic agent. Journal of Information, Intelligence and Knowledge, 4 (4): 295-307.

ISSN 1392-3196 / e-ISSN 2335-8947

Zemdirbyste-Agriculture, vol. 106, No. 1 (2019), p. 29-36

DOI 10.13080/z-a.2019.106.004

\title{
Sẻjamojo lino morfologinių savybių palyginimas kontroliuojamos ir natūralios aplinkos sąlygomis
}

\author{
K. Korolyov ${ }^{1}$, N. Bome ${ }^{1}$, L. Weisfeld ${ }^{2}$ \\ ${ }^{1}$ Tiumenès valstybinio universiteto Biologijos institutas, Rusija \\ ${ }^{2}$ Rusijos mokslų akademijos N. M. Emanuelio biocheminès fizikos institutas
}

\section{Santrauka}

Augalų genetinè ịvairovè didina pasirinkimo galimybę ir leidžia atrinkti augalus, labiau prisitaikiusius prie aplinkos sąlygų. Sėjamasis linas (Linum usitatissimum L.) yra vienas iš žemės ūkio augalų, kuriam reikia dèmesio ir įtraukimo ị žemès ūkio gamybą. Tobolsko srityje (Sibiras, Rusija) pirmieji bandymai su linais buvo pradèti dar 1908 metais. Dvidešimtajame amžiuje ši ūkio šaka buvo plètojama Tiumenès regiono ūkiuose. Šilumos resursai, dirvožemio agrocheminès savybės ir vandens ištekliai leidžia auginti linus šiose šiaurinèse platumose.

Tyrimo tikslas - nustatyti linų sèklų apdorojimo / beicavimo mutagenu fosfamidu įtaką chlorofilo kiekiui ir morfometriniams rodikliams linų daiguose ir augaluose. Tirta 17 pluoštinių ir 3 sėmeninių linų skirtingos kilmès (Rusijos, Baltarusijos, Ukrainos, Kanados, Čekijos, Prancūzijos ir Vokietijos) mėginių iš Tiumenès valstybinio universiteto Biologijos instituto kolekcijos. Orasausès sėklos buvo paveiktos 0,005, 0,01 ir 0,1\% koncentracijų fosfamido tirpalu. Laboratoriniai tyrimai atskleidè morfometrinių rodiklių skirtumus tarp linų daigų. Sėklų apdorojimo mutagenu poveikis nustatytas pagal chlorofilo kiekio skirtumus lapuose. Tirti genotipai skyrèsi chlorofilo kaupimosi dinamika ontogenezès tarpsniais. Visi genotipai į fosfamido koncentracijos didinimą reagavo mažindami chlorofilo kiekị lapuose.

Reikšminiai žodžiai: chlorofilo matavimas, fosfamidas, mutagenas, SPAD-502, stresorius. 